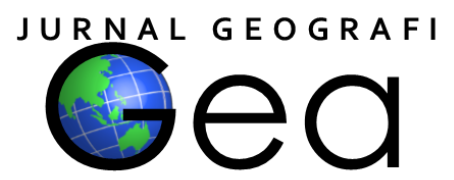

\title{
PENGARUH PERKEMBANGAN PARIWISATA TERHADAP KARAKTERISTIK EKONOMI MASYARAKAT DI SEKITAR CANDI BOROBUDUR
}

\author{
Arief Syaifuddin ${ }^{1}$, Joni Purwohandoyo ${ }^{2}$ \\ 1,2 Jurusan Geografi Pembangunan Universitas Gadjah Mada, Yogyakarta \\ ${ }^{1}$ Arief.syaifuddin@mail.ugm.ac.id, ${ }^{2}$ jonipurwo@ugm.ac.id
}

\begin{abstract}
Borobudur temple known as one of the famous international tourist destination. Beside supporting local economics, Borobudur temple also contributing in preservation world heritage. This research aims to analyst the impact of Borobudur temple as a tourist destination to the local economics. This research uses quantitative and qualitative approach with primary and secondary data collected by questionnaire, observation, literature studies, and in-depth interview. Analytical technique used are descriptive and frequency table. The impact of Borobudur temple as a tourist destination to the local economics is seen by the multiplier effect that gives direct impact, indirect impact, and induced impact. The research shows that the growth of Borobudur temple as a tourist destination is started when it was established as a tourist destination by the government in 1980. After that, Borobudur temple started to be known and visited by tourists and the infrastructures are growing gradually, such as better accessibility, well-equipped public facility, addition of tourist attraction, and participating society in accommodation procurement and a business doer in tourism sector. Society whose contributing in Borobudur's tourism activity comes to primary jobs and side jobs. The average income is $76,6 \%$ above minimum wage ratio in Magelang Regency and it is equal to the society's expense. Multiplier effect shows a number $\geq 1$ that makes the tourism activity has a significant impact to the local economics.
\end{abstract}

Keywords: multiplier effect, local economics characteristic, tourism

\begin{abstract}
ABSTRAK
Candi Borobudur dikenal sebagai salah satu destinasi wisata yang terkenal hingga manca negara. Selain mampu menyokong perekonomian masyarakat sekitar, keberadaan Candi Borobudur juga berkontribusi melestariakn warisan budaya dunia. Penelitian ini bertujuan menganalisis pengaruh perkembangan destinasi wisata Candi Borobudur terhadap ekonomi masyarakat sekitar. Penelitian ini menggunakan pendekatan kualitatif dan kuantitatif dengan pengumpulan data sekunder dan primer melalui kuesioner, observasi, studi literatur, dan wawancara mendalam. Teknik analisis yang digunakan deskriptif dan tabel frekuensi. Analisis pengaruh destinasi pariwisata terhadap ekonomi masyarakat dilihat dari efek penggandaan yang menghasilkan dampak langsung, dampak tidak langsung, dan dampak lanjutan. Hasil penelitian menunjukkan bahwa perkembangan destinasi pariwisata Candi Borobudur dimulai sejak candi ditetapkan sebagai objek wisata tahun 1980. Sejak terbentuk Candi Borobudur mulai banyak dikenal dan dikunjungi wisatawan sehingga terjadi penambahan berbagai aspek pengembang seperti akses jalan yang sudah diaspal, faslilitas pelayanan yang lengkap, atraksi wisata yang ditambah, dan masyarakat mulai terlibat dalam penyediaan akomodasi dan pelaku usaha di bidang pariwisata. Sedangkan karakteristik ekonomi masyarakat terlibat pada kegiatan pariwisata sebagai pekerjaan pokok maupun sampingan. Pendapatan yang diterima sebanyak $76,6 \%$ berada di atas UMK Kabupaten Magelang dan sebanding dengan pengeluaran masyarakat. Analisis efek penggandaan menunjukkan nilai $\geq 1$ yang berarti kegiatan pariwisata memberikan pengaruh berupa dampak terhadap perekonomian masyarakat.
\end{abstract}

Kaca kunci : pariwisata, karakteristik ekonomi masyarakat, efek penggandaan. 


\section{PENDAHULUAN}

Pariwisata merupakan salah satu sektor yang tumbuh dan berkembang di berbagai wilayah Indonesia. Perkembangan pariwisata tentu saja memberikan pengaruh terhadap pertumbuhan perekonomian suatu wilayah dengan harapan bahwa sektor tersebut mampu meningkatkan pendapatan wilayah. Pariwisata mampu mendorong sektor-sektor lain untuk ikut tumbuh dan berkembang bersama-sama. Menurut data Kementrian Pariwisata tahun 2015 menunjukkan bahwa sektor pariwisata menyumbang $10 \%$ PDB nasional yang merupakan nominal tertinggi di ASEAN. Produk Domestik Bruto (PDB) pariwisata nasional tumbuh $4,8 \%$ dengan tren naik sampai 6,9\%. Angka ini jauh lebih tinggi dibandingkan sektor lainnya yang cukup berkembang di Indonesia seperti industri agrikultur, manufaktur, dan pertambangan. Dalam penciptaan lapangan kerja, sektor pariwisata tumbuh $30 \%$ dalam kurun waktu 5 tahun dari tahun 2010 - 2015 (Kementrian Pariwisata, 2016).

Menurut Yoeti (2008), pariwisata dikatakan sebagai katalisator dalam pembangunan karena dampak yang diberikan terhadap perekonomian di negara yang dikunjungi wisatawan. Saat ini, pariwisata telah berfungsi sebagai agen perubahan (an agent of change) dimana perkembangan pariwisata disuatu area atau daerah tertentu dapat memberikan pengaruh terhadap pertumbuhan sektor ekonomi lainnya. Dengan adanya peran pariwisata yang digerakkan di suatu kawasan akan memberikan suatu konsekuensi atau pengaruh kepada masyarakat baik yang bersifat positif maupun negatif.

Pengaruh pariwisata terhadap ekonomi menurut memberikan dampak negatif atau dampak positif terhadap lingkungan ekonomi dalam kehidupan masyarakat sebagai akibat perkembangan pariwisata terhadap perubahan pekerjaan dan pendapatan masyarakat, pola pembagian kerja, kesempatan kerja dan berusaha. Salah satu destinasi wisata yang sudah lama dan menjadi salah satu destinasi wisata dunia adalah Candi Borobudur yang merupakan situs warisan dunia dengan nomor C-592. Menurut (Baiquni, 2009) Borobudur sebagai daya tarik atau magnet pariwisata merupakan salah satu aspek untuk memanfaatkan sekaligus mengkonservasi situs warisan budaya. Borobudur perlu alternatif yaitu berbasis pengetahuan dan pengalaman guna menemukan nilai-nilai salah satunya adalah nilai penghidupan (economy).

Secara geografis Candi Borobudur berada di Desa Borobudur, Kecamatan Borobudur, Kabupaten Magelang, Provinsi Jawa Tengah dan berbatasan langsung dengan Kota Magelang, Provinsi Jawa Tengah dan Kabupaten Sleman, Provinsi D.I Yogyakarta. Keberadaan Candi Borobudur mampu meningkatkan kunjungan wisatawan tidak hanya wisatawan domestik melainkan wisatawan mancanegara. Peningkatan jumlah wisatawan serta penetapan sebagai salah satu situs warisan dunia, mendorong pemerintah untuk menjadikan Candi Borobudur sebagai Kawasan Strategis Nasional menurut Peraturan Pemerintah No. 26 tahun 2008 tentang Rencana Tata Ruang Wilayah Nasional (Peraturan Pemerintah Republik Indonesia No. 26, 2008). Kawasan Strategis Borobudur mempunyai pengaruh sangat penting terhadap budaya yang berada dalam radius paling sedikit 5 (lima) kilometer dari pusat Candi Borobudur dan Koridor Palbapang, dapat dilihat pada gambar 1 .

Kegiatan pariwisata Candi Borobudur sudah terjadi sejak tahun 1980. Namun hal tersebut tidak menjadi jaminan bahwa kegiatan pariwisata di Candi Borobudur berkembang dan memberikan manfaat untuk sekitarnya terutama di sektor ekonomi. Karena pada kenyataannya Kecamatan Borobudur masih termasuk kecamatan termiskin di Kabupaten Magelang menurut BPS. Sehingga perlu dilihat sejauh mana perkembangan destinasi Candi Borobudur dan seberapa besar pengaruhnya terhadap perekonomia masyarakat. Mengingat sektor pariwisata merupakan sektor yang paling dominan di wilayah tersebut. Menurut Biantoro \& Ma'rif (2014), adanya perkembangan aktivitas pariwisata telah berpengaruh terhadap karakteristik sosial ekonomi masyarakat yang berada didalam kawasan wisata tersebut. Tetapi belum diketahui arah perkembangan pariwisata yang dimaksud yang memberi pengaruh terhadap perekonomian masyarakat sekitar candi, sehingga perlu diketahui sejauh mana pengaruh aktivitas pariwisata terhadap 
kondisi ekonomi masyarakat sekitar kawasan objek wisata Candi Borobudur.Berdasarkan gambaran tersebut, maka tujuan penlitian yang hendak dicapai adalah (1) mengidentifikasi perkembangan pariwisata Candi Borobudur;
(2) mengidentifikasi karaktersitik ekonomi masyarakat di sekitar Candi Borobudur (3) dan menganalisis pengaruh perkembangan pariwisata terhadap karakteristik ekonomi masyarakat sekitar Candi Borobudur.

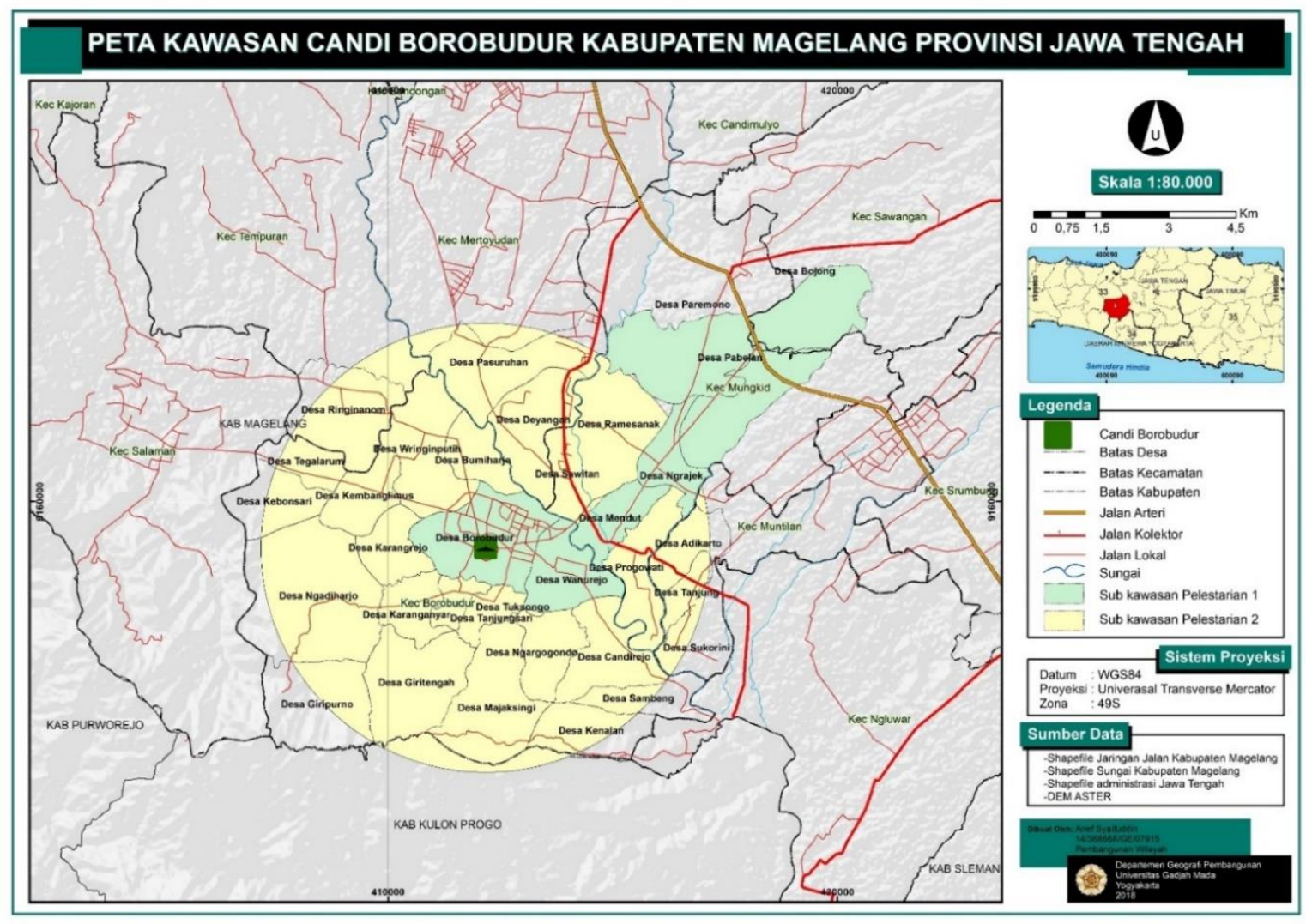

Sumber: Peraturan Pemerintah No. 26 Tahun 2008

Gambar 1. Peta Kawasan Candi Borobudur

\section{METODE PENELITIAN}

Penelitian ini menggunakan analisis deskriptif dan tabel frekuensi dengan pendekatan kuantitatif dan kualitatif. Pengumpulan data primer dilakukan dengan cara kuesioner, observasi, in depth interview, dan studi literatur. Cara pengumpulan data sekunder dilakukan dengan melakukan pengumpulan data yang terkait dengan perkembangan pariwisata yaitu indikatorindikator dari aspek atraksi, fasilitas, pelayanan, dan manajemen destinasi wisata serta data-data yang terkait dengan objek penelitian.

Sampel data diambil dengan metode stratified random sampling karena populasi yang dipilih mempunyai anggota/ unsur yang tidak homogen dan berstrata secara proporsional (Sugiyono, 2010). Pengambilan sampel menggunakan metode slovin dengan batas toleransi kesalahan 5\%. Populasi responden merupakan pelaku usaha/ pekerja di sektor pariwisata yang terlibat langsung dan tidak langsung pada wilayah dusun-dusun yang telah dilakukan sampling di Desa Borobudur. Jumlah populasi dalam penelitian ini adalah pelaku usaha di bidang pariwisata yang terlibat langsung (pekerja di PT TWC Borobudur) tidak langsung (di luar komplek Candi Borobudur) di dusun sampling. Populasinya yaitu 34 orang untuk yang terlibat lagsung pariwisata Candi Borobudur dan 169 populasi masyarakat yang tidak terlibat langsung. Perhitungan menggunakan rumus slovin menghasilkan jumlah sampel total sebanyak 150 responden untuk masyarakat yang terlibat langsung (31 sampel) dan tidak langsung (119) di bidang pariwisata. Waktu pelaksanaan penelitian dilakukan dari bulan Juli hingga September. 2018 untuk pengambilan data primer, sedangkan data sekunder diambil dari tahun 2010 hingga 2017 karena keterbatasan dan kelengkapan data. 


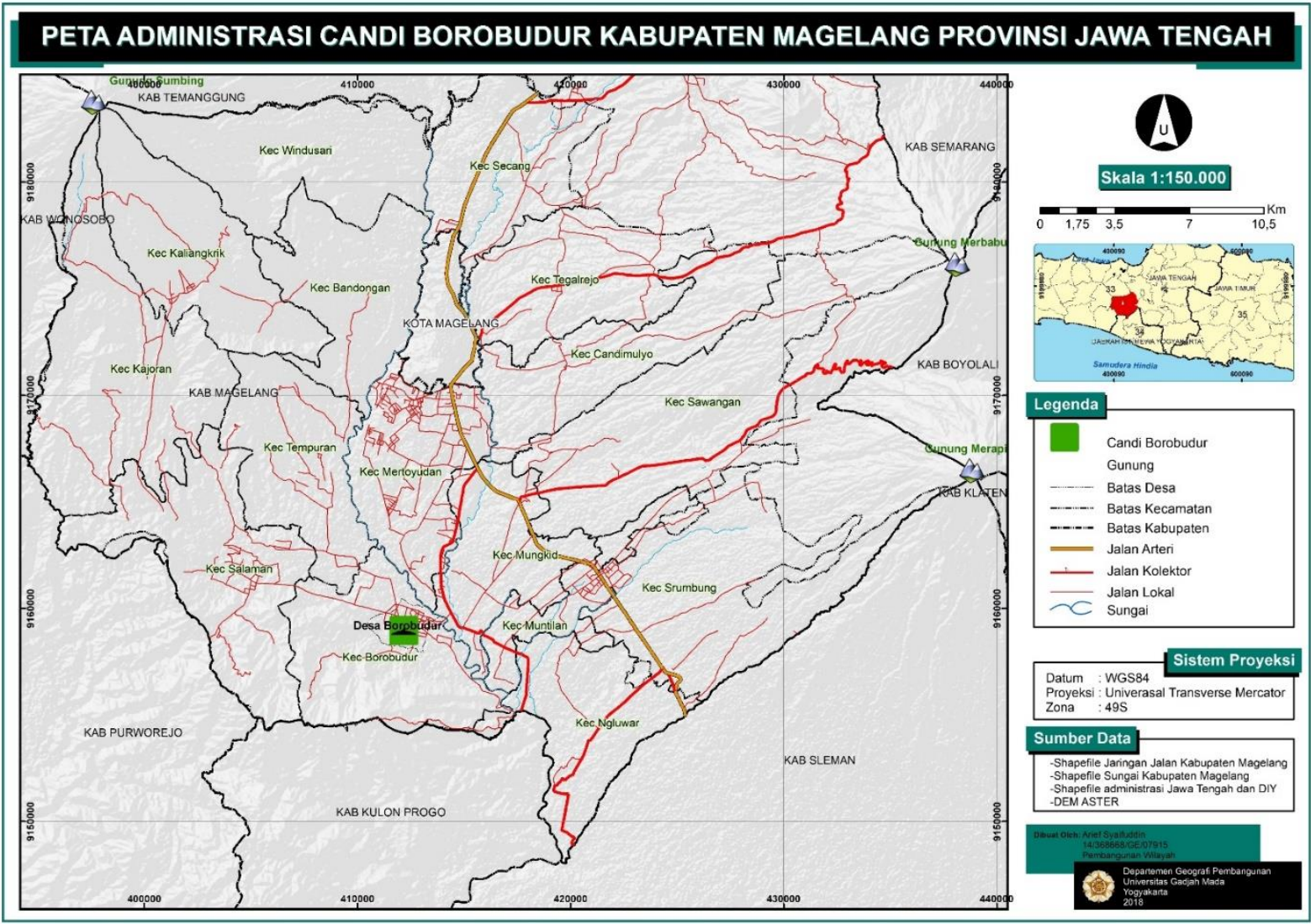

Sumber: Pengolahan Data Sekunder, 2018

Gambar 2. Peta Administrasi Candi Borobudur Kabupaten Magelang Jawa Tengah

Analisis data yang dilakukan berdasarkan pada masing-masing tujuan penelitian. Tujuan pertama, mengetahui perkembangan destinasi wisata Candi Borobudur dianalisis secara deskriptif kuantitatif dan kualitatif. Dalam hal ini hasil yang diperoleh dari data kualitatif berguna sebagai komplemen dan bukan pembanding dari hasil yang diperoleh dari data kuantitatif, begitu sebaliknya. Analisis deskriptif dibantu dengan penampilan tabel frekuensi, grafik, diagram, dan peta. Tujuan pertama menganalisis perkembangan destinasi pariwisata Candi Borobudur menggunakan konsep element destiantion yang dikemukakan Pallavicini (2017) yang terdiri dari aspek atraksi, fasilitas, pelayanan, dan manajemen destinasi wisata.

Tujuan kedua, mengidentifikasi karakteristik ekonomi masyarakat dilakukan dengan menggunakan analisis statistik deskriptif dengan menampilkan data dengan tabel frekuensi, tabulasi silang, grafik, dan diagram. Data kualitatif digunakan sebagai komplemen terhadap data kuantitatif. Analisis dilakukan berdasarkan paramater ekonomi masyarakat yang terdiri dari mata pencaharian, pendapatan, dan pengeluaran (Abdulsyani, 2013).

Tujuan ketiga, menganlisis pengaruh perkmbangan destinasi wisata Candi Borobudur terhadap ekonomi masyarakat yang dianalisis secara deskriptif analisis dengan menggunakan perhitungan dari efek penggandaan (multipplier effect). Nilai multiplier didapat berdasarkan peritungan berikut (META, 2001):

Keynesian Multiplier Effect

$$
\frac{\mathrm{D}+\mathrm{N}+\mathrm{U}}{\mathrm{E}}
$$

Ratio Income Multiplier, Tipe I

$$
\frac{\mathrm{D}+\mathrm{N}}{\mathrm{D}}
$$

Perhitungan Ratio Income Multiplier, Tipe II

$$
\frac{\mathrm{D}+\mathrm{N}+\mathrm{U}}{\mathrm{D}}
$$

Keterangan:

$\mathrm{D}=$ Pendapatan Lokal yang diterima langsung $\mathrm{N}=$ Pendapatan Lokal yang diterima tidak langsung $\mathrm{U}=$ Pendapatan Lokal yang diterima lanjutan $\mathrm{E}=$ Tambahan Pengeluaran Wisatawan 
Multipiler effect memiliki kriteria-kriteria sebagai berikut :

- Jika nilai koefisien multiplier tersebut kurang atau sama dengan nol $(\leq 0)$, maka destinasi wisata belum mampu memberikan dampak ekonomi terhadap aktivitas wisatanya.

- Jika nilai koefisien multiplier diantara nol dan satu $(0 \leq \mathrm{x} \leq 1)$, maka destinasi wisata memberikan nilai dampak ekonomi yang rendah.

- Jika nilai koefisien multiplier tersebut lebih atau sama dengan satu $(\geq 1)$, maka destinasi wisata mampu memberikan dampak ekonomi terhadap aktivitas wisatanya.

\section{HASIL DAN PEMBAHASAN \\ Perkembangan Pariwisata Candi \\ Borobudur}

Identifikasi perkembangan destinasi pariwisata Candi Borobudur dilakukan dengan melihat perkembangan jumlah unit pada masing-masing indikator pada setiap aspek dalam kurun waktu dari 2010-2017. Hal ini dilakukan karena keterbatasan data dan kekonsistenan data, namun tidak akan melemahkan hasil analisis.

\section{a. Atraksi Destinasi Pariwisata (Tourism Destination Attraction)}

Atraksi pada suatu destinasi wisata seperti Candi Borobudur sebagai indikator perkembangan candi tersebut dapat pula dilihat berdasarkan kunjungan wisatawan, perkembangan event/ kegiatan, perkembangan atraksi didalam kompleks dan luar candi, dan penghargaan yang diraih Candi Borobudur sebagai salah objek destinasi wisata. Secara garis besar perkembangan destinasi wisata Candi Borobudur dari aspek atraksi dapat dilihat pada tabel 1.

Indikator perkembangan atraksi juga termasuk didalamnya perkembangan event/ kegiatan dan tenaga kerja yang bertugas mengelola wisata Candi Borobudur. Event/ kegiatan yang diselenggarakan setiap tahunnya oleh pihak PT TWC sudah ada sejak tahun 2009, tetapi kegiatan yang selalu ada yang memang menjadi kegiatan rutin setiap tahunnya adalah perayaan waisak atau biasa disebut dengan Waisak Borobudur. Kegiatan tahunan yang ada di Candi Borobudur setiap tahunnya berbeda-beda meskipun cenderung sama, hal ini dikarenakan mitra yang menjadi sponsor kegiatan-kegiatan tersebut tidak sama setiap tahunnya.

Tabel 1. Perkembangan Atraksi Destinasi Wisata Candi Borobudur

\begin{tabular}{cccccc}
\hline \multirow{2}{*}{ Tahun } & $\begin{array}{l}\text { Keberadaan } \\
\text { Borobudur }\end{array}$ & $\begin{array}{l}\text { dan Jumlah } \\
\text { Event/ } \\
\text { Kegiatan }\end{array}$ & $\begin{array}{l}\text { Atraksi di } \\
\text { Kompleks Candi }\end{array}$ & $\begin{array}{l}\text { dalam } \\
\text { Atraksi } \\
\text { Candi }\end{array}$ & $\begin{array}{l}\text { sekitar } \\
\text { Kunjungan } \\
\text { Wisatawan }\end{array}$ \\
\hline \hline $\mathbf{2 0 1 0}$ & 6 & 5 & 5 & 2.408 .714 \\
\hline $\mathbf{2 0 1 1}$ & 6 & 5 & 5 & 2.125 .729 \\
\hline $\mathbf{2 0 1 2}$ & 6 & 6 & 5 & 3.021 .814 \\
\hline $\mathbf{2 0 1 3}$ & 6 & 6 & 5 & 3.374 .155 \\
\hline $\mathbf{2 0 1 4}$ & 6 & 6 & 5 & 3.395 .565 \\
\hline $\mathbf{2 0 1 5}$ & 7 & 6 & 5 & 3.649 .690 \\
\hline $\mathbf{2 0 1 6}$ & 7 & 6 & 5 & 3.870 .825 \\
\hline $\mathbf{2 0 1 7}$ & 13 & 7 & 6 & 3.900 .745 \\
\hline Sumber: Pengolahan Data (Dinas Pariwisata Pemuda dan Olahraga Kabupaten Magelang dan PT
\end{tabular}


Jumlah keseluruhan kunjungan wisatawan baik wisatawan domestik maupun mancanegara dari tahun 2010 hingga 2017 terjadi peningkatan maupun penurunan setiap tahunnya. Penurunan terjadi di tahun 2011 karena pada tahun tersebut merupakan pasca terjadinya bencana erupsi Gunung Merapi yang menyebabkan Candi Borobudur tertutup abu vulkanik. Akan tetapi, setelah tahun 2011 hingga tahun 2017 terjadi peningkatan kunjungan wisatawan sebanyak 20.000 hingga 850.000 pengunjung setiap tahunnya. Sejak dikelola tahun 1980, candi ini telah menerima beberapa penghargaan dari berbagai pihak, yang terbaru adalah penghargaan dari UNESCO dan PBB pada tahun 2017 berupa "Penghargaan Memory of The World (MoW)" atas arsip dokumentasi warisan dunia (Konvservasi Borobudur).

Semakin banyaknya unit pendukung atraksi menyebabkan wisatawan menjadi betah untuk berlama-lama disekitar Candi Borobudur. Hal ini juga sesuai dengan hasil lapangan yang menunjukkan wisatawan tidak hanya menikmati wisata "mendaki" hingga ke puncak Candi saja, tetapi wisatawan mencari hal yang beda dari pariwisata di Candi Borobudur, baik itu dengan penyuguhan ecent/ kegiatan tahunan, wahana, atraksi baru, dan berbagai daya tarik lainnya. Dengan demikian, dapat dikatakan atraksi destinasi Candi Borobudur cukup berkembang dengan ditunjukan kunjungan wisatawan yang meningkat tiap tahunnya.

\section{b. Fasilitas Destinasi Pariwisata (Tourism Destination Facilities)}

Keberadaan aspek fasilitas merupakan sesuatu yang sangat dibutuhkan wisatawan selama berada di daerah tujuan wisata. Secara garis besar perkembangan fasilitias dapat dijelaskan sebagai berikut.

Tabel 2. Perkembangan Fasilitas Wisata Candi Borobudur

\begin{tabular}{|c|c|c|c|c|c|c|}
\hline \multirow{2}{*}{ Tahun } & \multicolumn{6}{|c|}{$\begin{array}{c}\text { Keberadaan dan Jumlah Indikator Aspek Fasilitas Destinasi Candi } \\
\text { Borobudur }\end{array}$} \\
\hline & $\begin{array}{l}\text { Tempat } \\
\text { Parkir } \\
\end{array}$ & $\begin{array}{l}\text { Toilet } \\
\text { Umum } \\
\end{array}$ & $\begin{array}{l}\text { Tempat } \\
\text { Ibadah } \\
\end{array}$ & $\begin{array}{l}\text { Bank/ } \\
\text { ATM }\end{array}$ & $\begin{array}{c}\text { Apotek/ } \\
\text { Puskesmas } \\
\end{array}$ & $\begin{array}{l}\text { Kantor Polisi/ } \\
\text { Pos Satpam } \\
\end{array}$ \\
\hline 2010 & 4 & 10 & 11 & 10 & 3 & 12 \\
\hline 2011 & 4 & 10 & 11 & 10 & 3 & 12 \\
\hline 2012 & 4 & 10 & 11 & 14 & 4 & 12 \\
\hline 2013 & 4 & 10 & 11 & 14 & 4 & 12 \\
\hline 2014 & 4 & 10 & 14 & 14 & 4 & 12 \\
\hline 2015 & 4 & 10 & 14 & 14 & 4 & 12 \\
\hline 2016 & 4 & 10 & 14 & 14 & 4 & 12 \\
\hline 2017 & 4 & 10 & 14 & 14 & 4 & 12 \\
\hline
\end{tabular}

Sumber: Pengolahan Data (Dinas Pariwisata, Pemuda dan Olahraga Kabupaten Magelang dan PT Taman Wisata Candi Borobudur), 2018

Sejak awal diresmikan sebagai objek wisata, Candi Borobudur memiliki satu lapangan parkir yang luas di pintu masuk utama kompleks Candi Borobudur. Tempat parkir ini mampu memuat bus hingga kendaraan pribadi wisatawan yang berkunjung ke candi. Namun, pada saat hari libur terkadang lapangan tersebut tidak mampu menampung kendaraan pengunjung yang akhirnya banyak masyarakat sekitar yang membuka tempat parkir dadakan didepan halaman rumah mereka masing- 
masing. Fasilitas lainnya termasuk fasilitas umum yang harus tersedia disetiap pusat kegiatan yaitu fasilitas keuangan, kesehatan, dan keamanan. Fasilitas keuangan yang berkembang dapat diidentifikasi berdasarkan perkembangan jumlah bank, money changer, koperasi simpan pinjam maupun ATM di sekitar Candi Borobudur dimana sejak tahun 2010 sudah ada 10 fasilitas kemudian bertambah menjadi 14 fasilitas pada tahun 2012 yang terdiri dari 9 ATM dan 6 koperasi/ bank.

Berdasarkan hasil observasi dan wawancara dengan masyarakat sekitar memang ketersediaan tempat parkir menjadi masalah terutama di saat ramai wisatawan yang terkadang menimbulkan kemacetan. Daya tampung parkiran di area taman wisata Candi Borobudur memang kurang terutama di hari-hari libur sehingga banyak parkir kendaraan yang dialihkan ke permukiman warga. Selain itu, masalah pemusatan kelengkapan fasilitas memang berdasarkan hasil observasi terjadi pemusatan kegiatan terutama di sekitar jalan-jalan yang dilewati wisatawan. Namun terlepas dari masalah tersebut, perkembangan fasilitas pendukung pariwisata memang cukup berkembang berdasarkan indikator ketersediaan dan kualitas pelayanannya.

c. Pelayanan Destinasi Pariwisata (Tourism Destination Support Service)

Dukungan pelayanan pada suatu destinasi pariwisata dapat diukur berdasarkan jumlah paket wisata yang tersedia, kualitas aksesibilitas, dan akomodasi. Semakin lengkap dukungan pelayanan suatu destinasi wisata tentu akan semakin memudahkan wisatawan dalam melakukan kegiatan pariwisata. Secara garis besar perkembangan pariwisata Candi Borobudur dari aspke support service dapat dilihat sebagai berikut.

Tabel 3. Perkembangan Aspek Pelayanan Wisata Candi Borobudur

\begin{tabular}{|c|c|c|c|c|}
\hline \multirow{3}{*}{ Tahun } & \multicolumn{4}{|c|}{$\begin{array}{c}\text { Keberadaan dan Jumlah Indikator Aspek Pelayanan Dukungan Destinasi } \\
\text { Candi Borobudur }\end{array}$} \\
\hline & \multirow[b]{2}{*}{ Aksesibilitas } & \multicolumn{3}{|c|}{ Akomodasi } \\
\hline & & $\begin{array}{c}\text { Hotel/ } \\
\text { Homestay }\end{array}$ & Toko/ Minimarket & $\begin{array}{c}\text { Restoran/ Warung } \\
\text { Makan } \\
\end{array}$ \\
\hline 2010 & Jalan Aspal & 20 & 30 & 29 \\
\hline 2011 & Jalan Aspal & 20 & 33 & 34 \\
\hline 2012 & Jalan Aspal & 24 & 39 & 35 \\
\hline 2013 & Jalan Aspal & 30 & 44 & 37 \\
\hline 2014 & Jalan Aspal & 35 & 54 & 40 \\
\hline 2015 & Jalan Aspal & 41 & 70 & 41 \\
\hline 2016 & Jalan Aspal & 45 & 89 & 43 \\
\hline 2017 & Jalan Aspal & 49 & 107 & 43 \\
\hline
\end{tabular}

Perkembangan aspek pelayanan pariwisata dilihat dari perkembangan jumlah paket wisata yang tersedia dari awal terbentuk pengelolaan pariwisata di Candi Borobudur tahun 1980 hingga saat ini dari pihak pengelola menyediakan 1 paket wisata 
terusan dari Candi Prambanan, Ratu Boko, hingga Borobudur. Sedangkan dari luar pihak pengelola pariwisata Candi Borobudur terdapat berbagai macam paket wisata yang disediakan oleh jasa biro perjalanan. Ketersediaan paket wisata akan membantu wisatawan yang ingin menikmati wisata Candi Borobudur dan wisata-wisata lain disekitarnya.

Aspek pendukung pelayanan lainnya dapat pula dilihat dari perkembangan akomodasi wisata yang terdiri dari jasa penginapan, toko/ minimarket, dan restoran/ warung makan. Jasa penginapan meliputi hotel dan homestay yang mana akomodasi pertama kali berdiri adalah Homestay Anita 1 yang terletak di Dusun Jalan. Penginapan tersebut dimiliki oleh Bapak Sulaiman berdiri sekitar 25 tahun yang lalu atau tahun 1993 dan memperbanyak penginapannya dengan menambah Homestay Anita 2. Jasa penginapan ini pertama kali muncul pada tahun 2010 sebagai inisiatif dari masyarakat untuk terlibat dalam kegiatan pariwisata sekitar Candi Borobudur melalui penyediaan jasa penginapan.

Perkembangan akomodasi juga diukur dengan melihat perkembangan toko/ minimarket dan restoran/ warung makan. Perkembangan toko/ minimarket sudah ada sejak pengelolaan Candi Borobudur, namun jumlahnya masih sedikit. Begitu pula dengan restoran/ warung makan, hingga saat ini kedua akomodasi tersebut mengalami perkembangan dari segi jumlahnya dimana sudah banyak ditemui pertokoan dan warung makan disekitar candi.

\section{d. Manajemen Destinasi Pariwisata (Tourism Destination Management)}

Destinasi wisata yang baik diindikasikan apabila objek wisata tersebut memiliki kerjasama yang baik antar masyarakat maupun pihak lain dalam mengelola destinasi wisata tersebut. Berikut merupakan data perkembangan pariwisata Candi Borobudur dari aspek manajemen destinasinya.

Tabel 4. Perkembangan Manajemen Destinasi Wisata Candi Borobudur

\begin{tabular}{|c|c|c|c|}
\hline \multirow{2}{*}{ Tahun } & \multicolumn{3}{|c|}{ Jumlah Indikator Aspek Manajemen Destinas } \\
\hline & $\begin{array}{r}\text { Lembaga } \\
\text { Masyarakat }\end{array}$ & $\begin{array}{l}\begin{array}{l}\text { Pengelola } \\
\text { Candi } \\
\text { Borobudur }\end{array} \\
\end{array}$ & Tenaga Kerja \\
\hline 2010 & 3 & 2 & 542 \\
\hline 2011 & 3 & 2 & 560 \\
\hline 2012 & 3 & 2 & 534 \\
\hline 2013 & 3 & 2 & 526 \\
\hline 2014 & 3 & 2 & 513 \\
\hline 2015 & 3 & 2 & 563 \\
\hline 2016 & 3 & 2 & 559 \\
\hline 2017 & 3 & 2 & 557 \\
\hline
\end{tabular}

Lembaga masyarakat disekitar candi yang pertama kali terbentuk adalah Pokdarwis Borobudur bersamaan dengan mulai munculnya kegiatan pariwisata di Candi Borobudur sekitar tahun 1990 an. Kemudian, Warung Info Jagad Cleguk (WIJC) dibentuk pada tahun 2003 oleh Bapak Sucoro yang fokus kepada isu-isu yang berkembang pada pariwisata Candi Borobudur. Selain itu, semakin beragamnya kegiatan pariwisata sehingga butuh wadah untuk mengelompokkan masing-masing pelaku pariwisata Borobudur dalam satu wadah yaitu Klaster Pariwisata yang diketuai oleh Bapak Kerno Prasojo yang fungsinya sebagai tempat berkumpul dan 
tempat berdiskusi para pelaku usaha di bidang pariwisata.

Pengelolaan Candi Borobudur sejak awal terbagi menjadi dua kepentingan yaitu pertama yang bertugas/ bertanggung jawab dalam perawatan dan melestarikan Candi Borobudur adalah Balai Konservasi Borobudur (BKB) sejak tahun 1991. Tahun 1980, dalam rangka persiapan pengelolaan Taman Purbakala, didirikan PT. Taman Wisata Candi Borobudur (TWCB) dan Prambanan sebagai lembaga yang dipersiapkan untuk mengelola taman tersebut. Tahun 1983, proses pemugaran Candi Borobudur dinyatakan selesai dan dibuka untuk umum dengan upacara peresmian oleh Presiden RI Soeharto. Baru pada bulan tahun 1991, dikeluarkan Keputusan Presiden Republik Indonesia Nomor: 1 Tahun 1992 tentang Pengelolaan Taman Wisata Candi Borobudur dan Prambanan serta Pengendalian Lingkungannya.

Tabel 5. Jenis Pekerjaan Pokok Masyarakat Sekitar Candi Borobudur

\begin{tabular}{lccc}
\hline Jenis Pekerjaan & Jumlah Responden & $\begin{array}{l}\text { Persentase } \\
(\boldsymbol{\%})\end{array}$ & $\begin{array}{l}\text { Rata-rata } \\
\text { Bekerja (Tahun) }\end{array}$ \\
\hline \hline Agen Perjalanan & 1 & $1 \%$ & 3 \\
\hline Dinas TNI & 1 & $1 \%$ & 18 \\
\hline Karyawan PT TWC Borobudur & 29 & $19 \%$ & 10 \\
\hline Karyawan Swasta & 5 & $3 \%$ & 10,6 \\
\hline Pedagang & 66 & $44 \%$ & 14,1 \\
\hline Pegawai Jasa Penginapan & 7 & $5 \%$ & 2,8 \\
\hline Pegawai Toko & 10 & $7 \%$ & 7,5 \\
\hline Pemilik Jasa Penginapan & 20 & $13 \%$ & 8,85 \\
\hline Pengrajin & 1 & $1 \%$ & 30 \\
\hline Pensiunan & 2 & $1 \%$ & 2 \\
\hline Petani & 1 & $1 \%$ & 16 \\
\hline PNS & 3 & $2 \%$ & 8 \\
\hline Wiraswasta & 4 & $3 \%$ & 11,5 \\
\hline Total & 150 & $100 \%$ & Sumber: Pengolahan Data Primer, 2018
\end{tabular}

\section{Karakteristik Ekonomi Masyarakat Borobudur}

Karakteristik ekonomi masyarakat sekitar Candi Borobudur ada beberapa aspek untuk mengidentifikasinya yaitu dari aktifitas ekonomi yang dapat dijelaskan melalui struktur mata pencaharian masyarakat, pendapatan masyarakat, dan konsumsi barang/ jasa yang kemudian disebut sebagai pengeluaran masyarakat.

\section{a. Mata Pencaharian}

Struktur mata pencaharian masyarakat yang berada sekitar candi borobudur akan menunjukkan aktivitas ekonomi yang dominan terjadi yang kemudian akan menunjukkan karakter ekonomi masyarakat pada umumnya. Mata pencaharian dari pekerjaan utama maupun sampingan memiliki karakter yang berbeda. Berikut merupakan tabel jenis pekerjaan pokok masyarakat berserta sudah berapa lama masyarakat bekerja. 
Pekerjaan yang paling banyak diminati oleh masyarakat adalah di bidang perdagangan dan sebagai karyawan PT TWC Borobudur yaitu sebesar $44 \%$ dan $19 \%$. Selain itu juga pekerjaan dibidang jasa penginapan juga menjadi pekerjaan yang dominan dilakukan oleh masyarakat. Sebanyak 66 responden bekerja sebagai pedagang yang terdiri dari beberapa jenis pedagang. Pedagang yang paling sering dijumpai di sekitar candi adalah pedagang pakaian dan warung makan baik itu di dalam kompleks candi maupun diluar kompleks/ sekitar candi. Banyaknya pedagang yang bekerja dikarenakan keuntungan yang dihasilkan lebih besar dan tidak membutuhkan modal yang besar.

Pemilik jasa penginapan maupun pegawai jasa penginapan dijumpai sebanyak $18 \%$ masyarakat terlibat sebagai pelaku usaha tersebut. Kebanyakan masyarakat sebagai pemilik jasa penginapan terutama homestay mengubah tempat tinggal mereka menjadi penginapan. Tidak hanya sebagai penginapan saja, namun juga perdagangan lainnya, banyak dalam satu rumah yang menyediakan kios-kios hingga rumah makan didepan rumah mereka yang banyak dilalui oleh wisatawan. Pegawai jasa penginapan dan pegawai toko juga merupakan jenis pekerjaan yang juga dilakukan oleh masyarakat yang masingmasing sebanyak 5\% dan 7\%. Hal ini menjelaskan bahwa masyarakat cenderung untuk bekerja sebagai dengan orang lain dan tidak membuka usaha sendiri.

Selain itu, rata-rata lama bekerja dari masyarakat mengasumsikan sudah berapa lama jenis pekerjaan tersebut dilakoni masyarakat terutama untuk bidang pariwsata. Berdasarkan tabel, rata-rata lama bekerja masyarakat sekitar 11,5 tahun yang berarti bahwa sektor pariwisata sudah dikenal masyarakat sejak belasan tahun yang baru dan bukan hal yang baru bagi masyarakat sekitar. Rata-rata lama bekerja untuk sektor pariwisata yang paling lama adalah pengrajin dan pedagang. Terlihat bahwa masyarakat mulai menggeluti kerajinan sejak 30 tahun yang lalu dan pedagang rata-rata sejak 14 tahun yang lalu. Hal ini menunjukkan bahwa peluang usaha yang pertama dilihat masyarakat adalah di bidang perdagangan.

Hasil wawancara juga menunjukkan bahwa masyarakat pada awalnya melihat peluang bahwa jasa perdagangan pariwisata paling banyak digeluti masyarakat dan menjadi prioritas bagi masyarakat untuk dikembangkan. Toko-toko mulai bermunculan bersamaan dengan berkembangnya pariwisata Candi Borobudur dengan tujuan untuk memenuhi kebutuhan wisatawan mulai dari kebutuhan akan makan dan minum hingga souvenir yang memberikan kenangan bagi wisatawan. Selain pekerjaan pokok, masyarakat juga memiliki struktur mata pencaharian dari segi pekerjaan sampingan atau bisa dibilang pekerjaan tambahan. Hal ini dilakukan karena penghasilan yang didapatkan masih belum mampu memenuhi kebutuhan hidup atau motif lain yaitu untuk meningkatkan omset pendapatan yang kemudian dapat disimpan.

\section{b. Pendapatan}

Masyarakat yang menjadi responden memiliki pendapatan dari pekerjaan pokok dan sampingan dengan jumlah yang berbeda. Ratarata pendapatan responden pelaku usaha dari pekerjaan pokok dan sampingan yang berada di sekitar Candi Borobudur sebesar Rp. 4.961.486,00 per bulan dari total 150 responden.

Tabel 6. Tingkat Pendapatan Masyarakat (Responden) Sekitar Candi Borobudur per Bulan Berdasarkan Jenis Pekerjaan Pokok

\begin{tabular}{lcl}
\hline Kategori Pendapatan Masyarakat per Bulan & Jumlah Responden & Persentase (\%) \\
\hline \hline Rendah & 20 & $13 \%$ \\
\hline Sedang & 38 & $25 \%$ \\
\hline Tinggi & 34 & $23 \%$ \\
\hline Sangat Tinggi & 58 & $39 \%$ \\
\hline Total & 150 & $100 \%$ \\
\hline
\end{tabular}


Keterangan:

Rendah: Pendapatan <Rp.1.500.000,00

Sedang: Pendapatan Rp.1.500.000,00-

Rp.2.500.000,00

Tinggi: Pendapatan Rp.2.500.000,00-

Rp.3.500.000,00

Sangat Tinggi: Pendapatan >Rp 3.500.000

Sumber: Pengolahan Data Primer, 2018

Pendapatan masyarakat juga mengacu pada upah minimum yang ditetapkan oleh Dewan Pengupahan Kabupaten Magelang Tahun 2018. Kabupaten Magelang memiliki UMK sebesar Rp 1.706.747,00 (PP 78/2015 tentang Pengupahan). Berdasarkan data, hampir $76,6 \%$ masyarakat memiliki pendapatan rata-rata per bulan diatas UMK yang telah ditetapkan.

\section{c. Pengeluaran}

Pada dasarnya pengeluaran masyarakat ditentukan atas dasar banyaknya tanggungan anggota kelaurga dalam suatu rumah tangga. Asumsinya semakin banyak jumlah tanggungan keluarga maka semakin banyak pula pengeluaran yang harus dikeluarkan, begitu sebaliknya. Meskipun masih ada faktor-faktor lain yang mempengaruhinya, seperti tinggi rendahnya harga kebutuhan hidup, penghasilan dalam satu keluarga, serta faktor-faktor lainnya yang mempengaruhinya. Pengeluaran masyarakat dapat ditentukan dari tinggi rendahnya pendapatan yang didapat masyarakat untuk melihat kecendrungan asumsi bahwa apabila pendapatan yang tinggi makan pengeluarannya juga tinggi.

Tabel 7. Pengeluaran Masyarakat Sekitar Candi Borobudur per Bulan

\begin{tabular}{lcc}
\hline Pengeluaran Per Bulan & Jumlah Responden & Persentase (\%) \\
\hline \hline $\begin{array}{l}\text { Rendah } \\
(<\mathrm{Rp} \mathrm{1.000.000)}\end{array}$ & 24 & $16 \%$ \\
\hline $\begin{array}{l}\text { Sedang } \\
(\text { Rp 1.000.000-2.500.000) }\end{array}$ & 68 & $45 \%$ \\
\hline $\begin{array}{l}\text { Tinggi } \\
(>\text { Rp 2.500.000) }\end{array}$ & 58 & $39 \%$ \\
\hline Total & 150 & $100 \%$ \\
\hline
\end{tabular}

Pengeluaran masyarakat sekitar Candi Borobudur jika di rata-ratakan berkisar pada angka $\mathrm{Rp} 2.700 .000,00$ yang masuk kedalam kategori pengeluaran yang tinggi. Kategori tertinggi adalah pengeluaran dengan kategori sedang sebanyak $45 \%$ diikuti dengan kategori tinggi $39 \%$ dan kategori rendah hanya $16 \%$. Anggota keluarga yang paling mempengaruhi pengeluaran adalah jumlah anak. Kebutuhan anak dinilai lebih tinggi dibandingkan kebutuhan bapak atau ibu termasuk didalamnya kebutuhan pendidikan yang memang wajib bagi kebutuhan anak. Ratarata jumlah tanggungan masyarakat pelaku usaha di bidang perdagangan dan jasa pariwisata adalah tiga jiwa dalam satu rumah.

\section{Pengaruh Perkembangan Pariwisata terhadap Ekonomi Masyarakat Borobudur}

Perkembangan pariwisata melalui aspek-aspek destinasi wisata secara tidak langsung memberikan pengaruh tidak langsung terhadap parameter ekonomi masyarakat. Analisis dilakukan dengan melihat dampak terhadap ekonomi masyarakat yaitu efek penggandaan (Multiplier Effect) yang terdiri dari dampak langsung (direct impact), dampak tidak langsung (indirect impact), dan dampak lanjutan (Induced Impact). Ketiga dampak ini merupakan pengaruh oleh adanya perkembangan destinasi wisata Candi Borobudur terhadap ekonomi masyarakat yang dilihat dari pendapatan, pengeluaran, dan mata pencaharian masyarakat sekitar Candi Borobudur. Untuk lebih jelasnya dapat dilihat pada gambar 3 . 


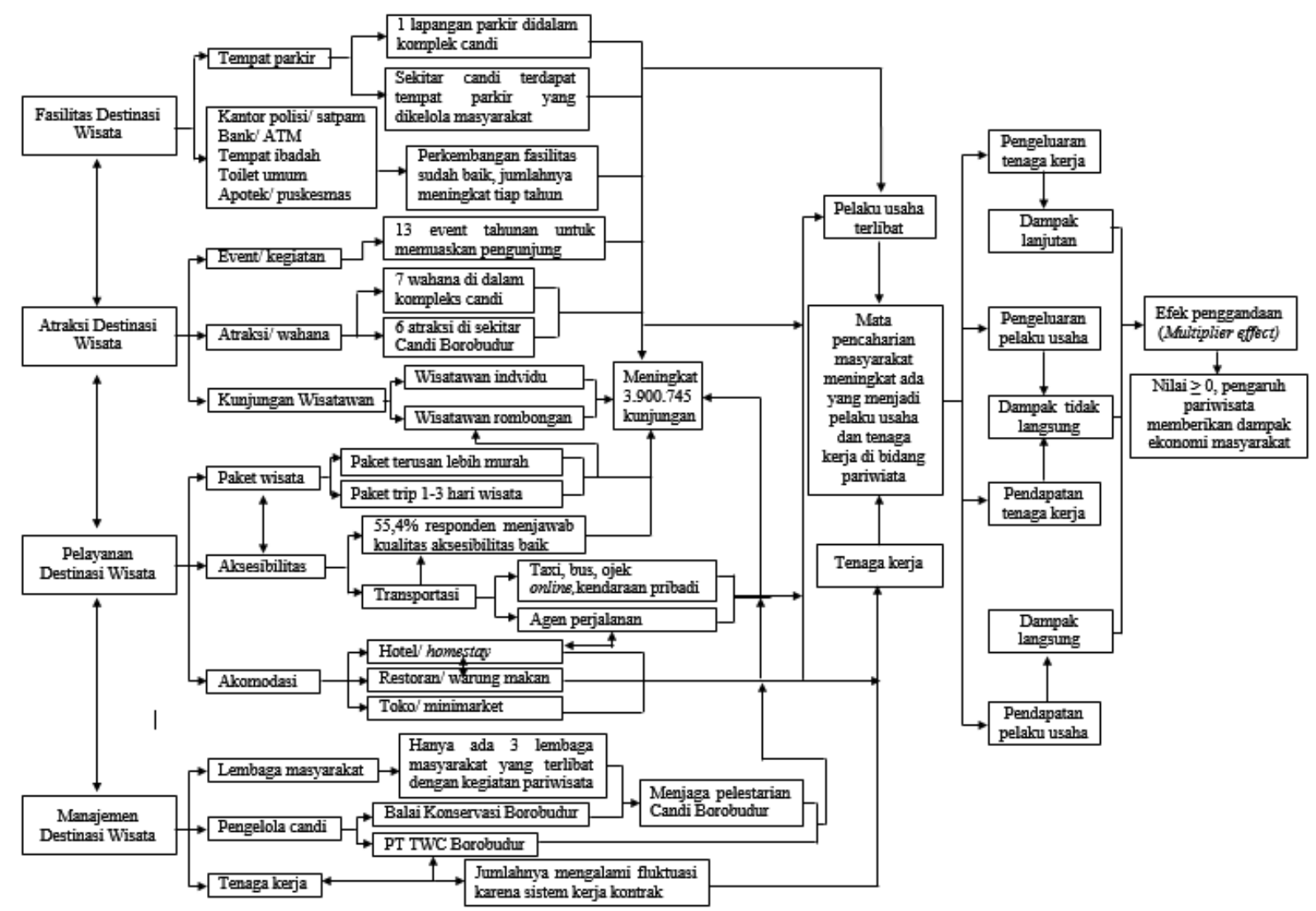

Sumber: Analisis Data, 2018

Gambar 3. Alur Pengaruh Perkembangan Candi Borobudur terhadap Ekonomi Masyarakat

Aspek atraksi destinasi pariwisata yang terdiri dari indikator event/ kegiatan, atraksi di dalam kompleks dan sekitar Candi Borobudur, dan jumlah kunjungan memang secara tidak langsung memberikan pengaruh terhadap ekonomi masyarakat. Jumlah kunjungan yang meningkat karena event dan atraksi yang disediakan meningkat memberikan dampak langsung terhadap pelaku usaha dan sektor perdagangan yang berhubungan dengan pariwisata.Penyediaan pelayanan berupa paket wisata, akomodasi, dan aksesibilitas memunculkan dampak langsung terutama pelaku usaha pada indikator pelayanan seperti agen perjalanan, jasa penginapan, pertokoan, dan rumah makan yang meningkatkan lapangan kerja bagi masyarakat sekitar. Dampak langsung sebagai pengaruh dari pariwisata terhadap ekonomi masyarakat dilihat dari pendapatan yang diterima pelaku usaha dibidang pariwisata.

Aspek manajemen destinasi berhubungan dengan upaya pengelolaan Candi Borobudur oleh beberapa pihak yaitu antara masyarakat, pihak swasta, dan pemerintah untuk menciptakan sistem pengelolaan yang saling menguntungkan. Pengaruh aspek fasilitas pada destinasi pariwisata Candi Borobudur secara logika tidak memberikan dampak terhadap ekonomi masyarakat. Pengaruh yang diberikan yaitu secara tidak langsung, dimana ketika jumlah kunjungan wisatawan meningkat maka kebutuhan wisatawan akan meningkat pula.

Secara umum, pengaruh dari masingmasing aspek terhadap ekonomi masyarakat menghasilkan efek penggandaan (multiplier effect). Koefisien nilai dari perhitungan efek penggandaan akan mengindikasikan pengaruh dari pariwisata terhadap ekonomi masyarakat. Berikut hasil perhitungan nilai pengaruh dari multiplier effect.

Berdasarkan tabel 8 nilai dari Keynesian Income Multiplier adalah sebesar 2,82, artinya bahwa setiap peningkatan satu rupiah pengeluran yang dilakukan oleh wisatawan Candi Borobudur akan memiliki dampak terhadap ekonomi mastarakat 
sekitar sebesar 2,82 rupiah. Nilai Keynesian Income Multiplier merupakan nilai tertinggi diantara nilai multiplier lainnya karena nilai koefisiennya memperhitungkan seluruh nilai dampak ekonomi secara langsung dan jumlah pengeluaran yang dilakukan oleh wisatawan Candi Borobudur. Nilai Ratio Income Multiplier, Tipe I adalah sebesar 1,54 yang berarti setiap peningkatan satu rupiah pada penerimaan pelaku usaha pada masyarakat Candi Borobudur akan mengakibatkan peningkatan sebesar 1,54 rupiah terhadap pendapatan pelaku usaha dan pendapatan tenaga kerja. Sedangkan nilai Ratio Income Multiplier, Tipe II sebesar 1,63, artinya bahwa setiap peningkatan satu rupiah pada penerimaan pelaku usaha akan mengakibatkan peningkatan sebesar 1,63 pada pendapatan pelaku usaha, pendapatan dan pengeluaran tenaga kerja. Ketiga efek ini berbanding lurus dengan koefisien yang ditunjukkan bernilai positif.
Secara keseluruhan, ketiga dampak tersebut menghasilkan pengaruh perkembangan pariwisata berupa efek penggandaan (multiplier effect) terhadap ekonomi masyarakat sekitar Candi Borobudur. Berdasarkan hasil perhitungan nilai efek penggandaan menunjukkan angka lebih besar atau sama dengan satu $(\geq 1)$ untuk setiap nilai multiplier yaitu. Apabila ketiga nilai multiplier tersebut lebih besar atau sama dengan satu maka suatu kawasan destinasi wisata mampu memberikan perngaruh berupa dampak ekonomi terhadap kegiatan wisatanya. Artinya adalah kegiatan destinasi wisata Candi Borobudur telah mampu memberikan pengaruh berupa dampak ekonomi bagi kegiatan ekonomi pariwisata masyarakat sekitar Candi Borobudur. Hal ini menunjukkan bahwa perkembangan destinasi pariwisata Candi Borobudur memberikan pengaruh terhadap ekonomi masyarakat sekitar berupa efek pengganda yang terdiri dari dampak langsung, tidak langsung, dan lanjutan.

Tabel 8. Nilai Pengaruh Multiplier Effect Destinasi Wisata Candi Borobudur terhadap Ekonomi Masyarakat

\begin{tabular}{lc}
\hline Pengaruh Multipiler Effect & Nilai* $^{*}$ \\
\hline \hline Keynesian Income Multiplier & 2,82 \\
\hline Ratio Income Multiplier, Tipe I & 1,54 \\
\hline Ratio Income Multiplier, Tipe II & 1,63 \\
\hline
\end{tabular}




\section{SIMPULAN}

Hasil identifikasi melalui empat aspek perkembangan destinasi wisata menunjukkan bahwa Candi Borobudur sebagai objek wisata mengalami perkembangan dengan baik. Hal ini dibuktikan dengan jumlah wisatawan yang meningkat setiap tahunnya baik wisatawan mancanegara maupun domestik, fasilitas yang jumlahnya sudah memadahi, kondisi jalan hingga saat ini sudah membaik, banyak jalan yang sudah diaspal dan mengalami perbaikan, jasa penginapan mengalami peningkatan terutama homestay, dan manajemen pariwisata sudah terorginisir dengan baik. Pemerintah, perusahaan/ swasta, dan masyarakat bekerja sama dan memiliki peran masing-masing dalam kegiatan pariwisata.

Karakteristik ekonomi masyarakat sekitar Candi Borobudur terbagi dua yaitu masyarakat yang menjadikan bidang pariwisata sebagai sumber mata pencaharian utama dan sebagai sumber mata pencaharian sampingan. Hasilnya menunjukkan bahwa perekonomian masyarakat tergolong cukup baik dengan sebanyak $76,6 \%$ pendapatan berada di atas UMK. Semakin banyak pengeluaran akan sebanding dengan jumlah tanggungan keluarga dan pendapatan yang dihasilkan. Hal ini sesuai dengan tingkat pemenuhan kebutuhan masyarakat $92 \%$ terpenuhi.

Pengaruh aspek perkembangan destinasi wisata terhadap parameter ekonomi masyarakat dianalisis berdasarkan efek penggandaan, hasil perhitungan nilai multiplier effect menghasilkan nilai diatas atau sama dengan 1 untuk setiap koefisien multiplier-nya. Hal ini menunjukkan bahwa perkembangan destinasi pariwisata Candi Borobudur memberikan pengaruh terhadap ekonomi masyarakat sekitar berupa efek pengganda yang terdiri dari dampak langsung, tidak langsung, dan lanjutan.

\section{REKOMENDASI}

Perkembangan pariwisata terutama destinasi wisata sebetulnya terdiri dari komponen/ aspek yang lebih kompleks lagi untuk menyatakan bahwa suatu destinasi tersebut benar-benar berkembang. Masyarakat sekitar yang terlibat sebagai pelaku usaha atau tenaga kerja bidang pariwisata agar dapat memanfaatkan peluang dan menciptakan ide atau inovasi baru dalam menyediakan pelayanan bagi wisatawan dan bagi pengelola agar lebih melibatkan masyarakat untuk menyeimbangkan perekonomian wilayah tersebut. Semua stakeholder yang terkait terutama pemerintah Kabupaten Magelang untuk lebih bekerja sama dengan pihak pengelola Candi Borobudur yaitu PT Taman Wisata Candi Borobudur begitu pula sebaliknya agar tercipta pengaruh yang lebih besar dampaknya terhadap ekonomi masyarakat.

\section{DAFTAR PUSTAKA}

A. Yoeti, O. (2008). Ekowisata Pariwisata: Introduksi, Informasi, dan Implementasi. Jakarta: Kompas.

Abdulsyani. (2013). Sosiologi: Skematika, Teori, dan Terapan. Jakarta: PT. Bumi Aksara.

Adhikari, R. K. (2009). Economic of Organik vs Inorganik Carrott Production in Nepal. The Journal of Agriculture and Environment, 10, 27-33.

Baiquni, M. (2009). Belajar dari Pasang Surut Peradaban Borobudur dan Konsep Pengembangan Pariwisata Borobudur. Jurnal Forum Geografi, Vol. 23, No. 1, 2540.

Jazmin Ariana Corrales Pallavicini, P. J.-E. (2017). Factors Influencing Tourism Destinations Attractiveness The Case of Malaga. Jerman: Redboud University.

Kementerian Pariwisata. (Online). "Rencana Tata Ruang Wilayah Nasional". Tersedia di https://web.kominfo.go.id/sites/default/files /Paparan\%20Kemenpar\%20untuk\%20KID I\%202016.pdf diakses tanggal 11 November 2017.

[META] Marine Ecotourism for Atlantic Area. 2001. Planning for Marine Ecotourism in The Eu Atlantic Area. Britol (GB): University of The West Of England. 